\title{
Testosterone and progesterone in peripheral plasma during the oestrous cycle of the mare
}

\author{
P. Silberzahn*, D. Quincey*, C. Rosier* and P. Leymarie† \\ *Laboratoire de physico-chimie biologique, U.E.R. des Sciences de la Vie and \\ $\dagger$ Laboratoire de Biochimie, U.E.R. de Médecine, Université de Caen-14000, France
}

\begin{abstract}
Summary. Measurements every day or every other day showed that testosterone levels ranging from 15 to $70 \mathrm{pg} / \mathrm{ml}$ were higher at oestrus in 4 of the 6 mares studied. In these 4 mares, another testosterone peak occurred 11-13 days before the next oestrus either before ( 3 mares) or after the fall in progesterone levels.
\end{abstract}

\section{Introduction}

Many reports relating to the concentration of steroids in the blood plasma of the mare have appeared recently (see Rowlands, Allen \& Rossdale, 1975). Most of these reports deal with progesterone and its fluctuations throughout the oestrous cycle and pregnancy or with oestrogens and androstenedione (Nett, Holtan \& Estergreen, 1973; Pattison, Chen, Kelly \& Brandt, 1974; Noden, Oxender \& Hafs, 1975 ), but there is no information about the levels of plasma testosterone in the mare. In the present study, therefore, simultaneous measurements of plasma testosterone and progesterone in mares were taken during the oestrous cycle.

\section{Materials and Methods}

Animals. Six mares were maintained in normal stud conditions and blood samples were taken during the months of May and June. Two Arabian mares, CHA and ROU, 5 and 11 years old respectively, were sampled daily for 2 consecutive oestrous cycles (CHA) and for one cycle only (ROU). Blood was collected every other day and during one cycle only from 4 mares (Selle Français), SY, NO, DE and DA which were 19,21, 5 and 9 years old respectively. Blood was always withdrawn from the jugular vein at 10:00 h, collected in heparinized plastic tubes, centrifuged immediately and the plasma stored at $-20^{\circ} \mathrm{C}$. The day of ovulation was routinely determined by daily palpation of the ovaries through the rectal wall.

Assays. Testosterone was measured in duplicate samples by the radioimmunoassay method of Collins, Mansfield, Alladina \& Sommerville (1972), slightly modified as described by Leymarie, Strauss \& Scholler (1974). In brief, $2 \mathrm{ml}$ plasma were extracted with diethylether after the addition of a trace amount of $\left[{ }^{3} \mathrm{H}\right]$ testosterone (sp. act. $80-100 \mathrm{Ci} / \mathrm{mmol}$ ) for estimation of recovery. The crude extract was purified on a microcolumn of Sephadex LH-20. The antigen-antibody equilibrium reaction was performed at $37^{\circ} \mathrm{C}$ for $40 \mathrm{~min}$ and the unbound steroid was separated from the bound by an extraction with toluene at $4^{\circ} \mathrm{C}$. The between-assay coefficient of variation, calculated from control samples, was $13 \%$ and the within-assay coefficient of variation calculated from two sets of six assays was $5.6 \%$. The sensitivity of the method, as defined by Currie (1968), was $3 \mathrm{pg} / \mathrm{ml}$ of plasma. The antiserum was raised in rabbits against testosterone-3-carboxymethyl-oxime-BSA. Of all the $\mathrm{C}_{18}, \mathrm{C}_{19}$ and $\mathrm{C}_{21}$ steroids examined, only $17 \beta$-hydroxy-5 $\alpha$-androstan-3-one (DHT) showed significant crossreactivity $(50 \%)$ with the testosterone antiserum. DHT was not separated from testosterone by our purification procedure, but its concentration in mare plasma which was measured in a separate study (unpublished results) was found to be less than $20 \%$ of the testosterone content. Progesterone was 
measured by a similar radioimmunoassay, including purification on Sephadex LH-20, with an antiserum raised against progesterone-3-carboxymethyl-oxime-BSA. The between-assay and withinassay coefficients of variation, calculated as for testosterone, were 13 and $5 \%$ respectively. The sensitivity was $10 \mathrm{pg}$. The only compounds that cross-reacted with this antibody were $5 \alpha$-pregnane3,20 -dione $(69 \%)$ and $5 \beta$-pregnane-3,20-dione $(11 \%)$.

\section{Results}

The testosterone and progesterone concentrations in the four mares bled every other day are given in Table 1 and those for Mares CHA and ROU are illustrated in Text-fig. 1. The rise in progesterone levels, correlated with a functional corpus luteum, confirmed the occurrence of ovulation in each mare. The pattern of change of testosterone concentrations was more variable. In Mares CHA, DE and DA there was a rise of plasma testosterone at about the time of ovulation and on Days 9,10 or 11 , just before luteolysis. There were no obvious fluctuations of testosterone in Mares SY and NO. In Mare ROU, the cycle was 30 days long and the mid-cycle peak clearly occurred after the fall of plasma progesterone.

\section{Discussion}

Data from the literature concerning testosterone levels and variations throughout the oestrous cycle in mammals are scarce. However, Shemesh \& Hansel (1974), and Kanchev, Dobson, Ward \& Fitzpatrick (1976) have reported that there is a rise in testosterone shortly before ovulation in the cow. Similarly, a rise of plasma testosterone is known to occur around the time of ovulation day in women (Abraham, 1974). In the cow a second rise of plasma testosterone, 7 days before ovulation, was found by Kanchev et al. (1976) and this rise preceded the day on which plasma progesterone began to decrease. Peterson, Fairclough \& Smith (1978), however, found no consistent changes in testosterone or androstenedione levels at any stage of the cycle of the cow. The physiological significance of the second testosterone rise observed by Kanchev et al. (1976) in the cow and by ourselves in at least some of the mares is not easy to interpret. In Mare ROU, in which the length of the cycle was unusually long but the life-span of the corpus luteum was normal, the second testosterone peak clearly occurred after the plasma progesterone fall, suggesting that it is independent from the progesterone level. The suggestion of Kanchev et al. (1976), that this "increased testosterone secretion" could be necessary for normal luteal regression in the cow does not seem to hold true for the mare.

Gonadotrophin measurements were not performed in the present study, but LH and FSH levels reported in the literature can be compared with the fluctuations of testosterone. In the mare, $\mathrm{LH}$ levels exhibit a single preovulatory rise, reaching maximal values either during the day of ovulation or in the next 2 or 3 days (Whitmore, Wentworth \& Ginther, 1973; Pattison et al., 1974). There are two phases of elevated FSH levels; one is concomitant with the LH peak during late oestrus and early dioestrus and the other occurs during mid-dioestrus when there is no simultaneous increase in $\mathrm{LH}$ level (Evans \& Irvine, 1975). This second FSH peak was said by Evans \& Irvine (1975) to occur "almost without exception 10 to 13 days before the next ovulation, despite extreme variability between mares in total cycle length". It therefore seems possible that the testosterone and FSH rises which occur between Days -13 and -10 before the next ovulation might be related.

In the rat, a correlation between testosterone secretion and FSH release has been reported by Gay \& Tomacari (1974), who demonstrated that the suppression of circulating androgens by treatment with an antiserum against testosterone inhibits the preovulatory peak of FSH secretion.

Further investigations are necessary to explore the possibility of an androgen dependence of FSH secretion in the mare. 


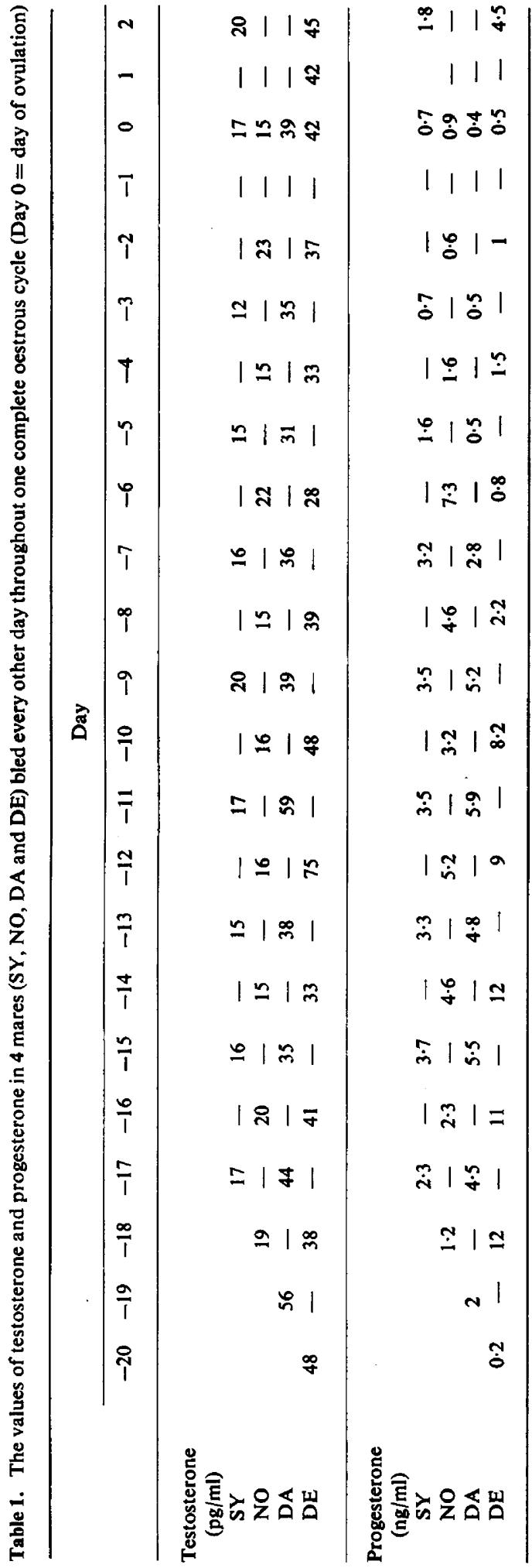




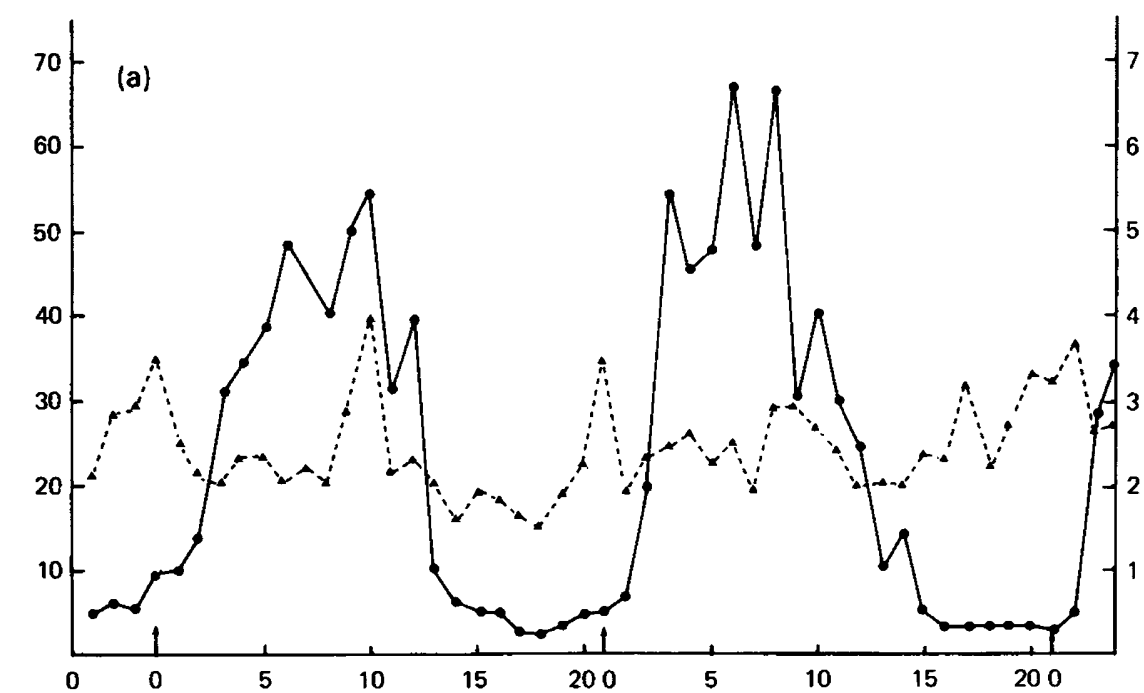

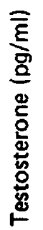

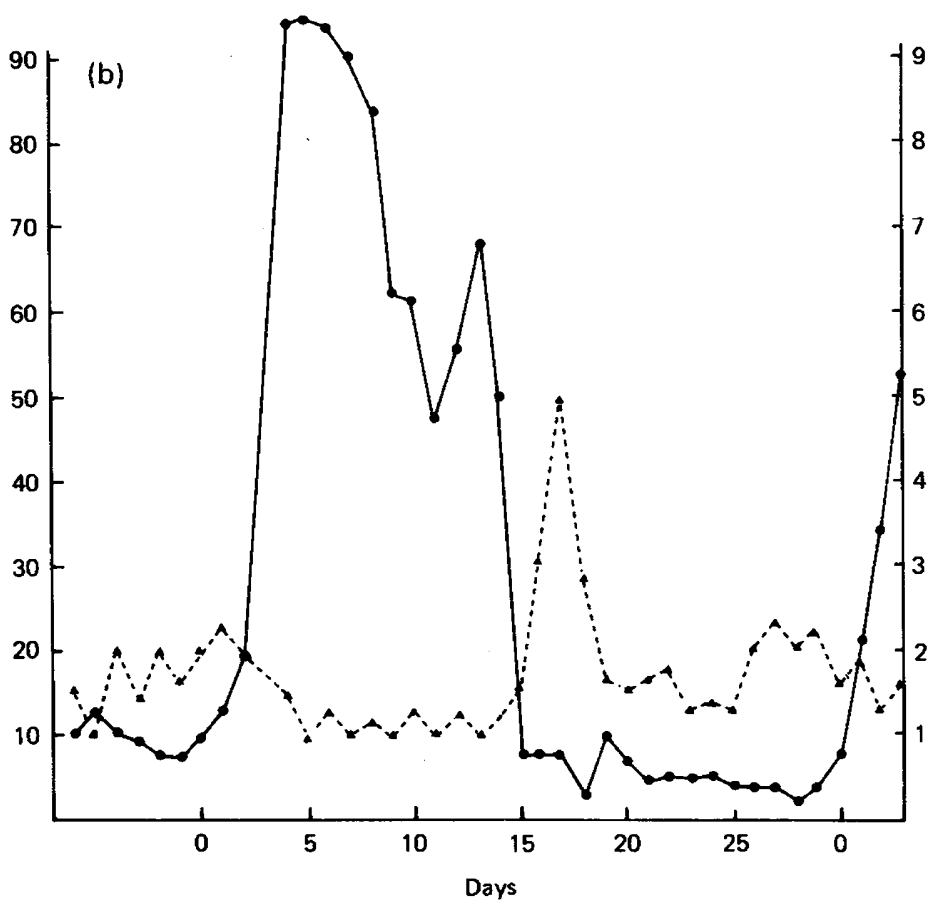

Text-fig. 1. Daily variations of progesterone ( $)$ and testosterone ( $\Delta$ ) during (a) two oestrous cycles of Mare CHA and (b) one oestrous cycle of Mare ROU. Day 0 was the day of ovulation.

\section{References}

ABRAHAM, G.E. (1974) Ovarian and adrenal contribution to peripheral androgens during the menstrual cycle. J. clin. Endocr. Metab. 39, 340-347.
Collins, W.P., Mansfield, M.D., Alladina, N.S. \& SOMMERVILLE, I.F. (1972) Radioimmunoassay of plasma testosterone. J. Steroid Biochem. 3, 333-348. 
Currie, L.A. (1968) Limits for qualitative detection and quantitative determination. Application to radiochemistry. Am. Chem. 40, 586-593.

Evans, M.J. \& IRvine, C.H.G. (1975) The serum concentrations of $\mathrm{FSH}, \mathrm{LH}$, and progesterone in the oestrous cycle and early pregnancy in the mare. $J$. Reprod. Fert., Suppl. 23, 193-200.

GAY, V.L. \& TOMACARI, R.L. (1974) Follicle-stimulating hormone secretion in the female rat: cyclic release is dependent on circulating androgen. Science, $N$. $Y$. 184, 75-77.

Kanchev, L.N., Dobson, H., Ward, W.R. \& FitzPATRICK, R.J. (1976) Concentration of steroids in bovine peripheral plasma during the oestrous cycle and the effect of betamethasone treatment. J. Reprod. Fert. 48, 341-345.

Leymarie,P., Strauss, N. \& Scholler, R. (1974) Dosage radioimmunologique rapide de la testostérone plasmatique chez l'adulte et l'enfant. Vérification de la spécificité par dosage en spectrométrie de masse. Path. Biol. 22, 877-882.

Nett, T.M., Holtan, D.W. \& Estergreen, V.L. (1973) Plasma estrogens in pregnant and postpartum mares. J. Anim. Sci. 37, 962-970.

Noden, P.A., Oxender, W.D. \& Hafs, H.D. (1975) The cycle of oestrus, ovulation and plasma levels of hor- mones in the mare. J. Reprod. Fert., Suppl. 23, 189192.

Pattison, M.L., Chen, C.L., Kelley, S.T. \& BrandT, G.W. (1974) Luteinizing hormone and estradiol in peripheral blood of mares during estrous cycle. Biol. Reprod. 11, 245-250.

Peterson, A.J., Fairclough, R.J. \& Smith, J.F. (1978) Radioimmunoassay of androstenedione and testosterone in cow plasma at the time of luteolysis and oestrus. J. Reprod. Fert. 52, 127-129.

Rowlands, I.W, Allen, W.R. \& Rossdale, P.D. (Eds) (1975) Equine Reproduction, J. Reprod. Fert., Suppl. 23.

SHEMESH, M. \& HANSEL, W. (1974) Measurement of bovine plasma testosterone by radioimmunoassay and by a rapid competitive protein binding assay. $J$. Anim. Sci. 39, 720-724.

WhitMore, H.L., Wentworth, B.C. \& Ginther, O.J. (1973) Circulating concentrations of luteinizing hormone during estrous cycle of mares as determined by radioimmunoassay. Am. J. vet. Res. 34, 631-636.

Received 15 April 1977 